\title{
Enlargement of the salivary gland after ritodrine treatment in pregnant women
}

\author{
Hisanori Minakami, Tsutomu Takahashi, Akio \\ Izumi, Hideo Itoi, Taro Tamada
}

Department of Obstetrics and Gynaecology, Jichi Medical School,

Minamikawachi-machi, Tochigi 329-04, Japan Hisanori Minakami, assistant professor

Tsutomu Takahashi, research fellow

Akio Izumi, research fellow Hideo Itoi, research fellow

Taro Tamada, professor Minakami.

BMf 1992;304: 1668
Correspondence to: $\mathrm{Dr}$

Preterm labour continues to complicate a substantial number of pregnancies, and preterm delivery accounts for most early neonatal deaths not due to congenital abnormalities.' Ritodrine hydrochloride, a $\beta$ sympathomimetic agent with predominant effects on $\beta$ receptors such as those of the uterus, ${ }^{2}$ is effective in suppressing premature uterine contractions. ${ }^{2}$ We describe six pregnant women given ritodrine hydrochloride who developed swelling of the salivary glands with hypersecretion of amylase.

\section{Patients and results}

From May 1990 to October 1991 we treated 150 pregnant women with premature uterine contractions with ritodrine hydrochloride. The drug was administered intravenously in a solution containing $50 \mathrm{mg}$ of ritodrine hydrochloride in $500 \mathrm{ml}$ of $5 \%$ glucose. The solution was administered at a rate of $50 \mu \mathrm{g} / \mathrm{min}$, increased by $50 \mu \mathrm{g} / \mathrm{min}$ every $20-30$ minutes in response to continued uterine activity until tocolysis or toxicity occurred or a dose of $350 \mu \mathrm{g} / \mathrm{min}$ was reached.

Of the 150 patients six developed symptoms of parotitis after the administration of ritodrine (table). Each of the women complained of swelling of the cheeks in the first 24 hours after treatment; some also had swelling of the submandibular area. These swellings were easily felt by palpation. Four patients (cases 1 to 4$)$ had a low grade fever $\left(37 \cdot 2-38 \cdot 0^{\circ} \mathrm{C}\right)$ which lasted for up to two days. The total dose used in these six patients varied from $184-2900 \mathrm{mg}$, given over 11 hours to 26 days. The swelling resolved within five days in all cases. Since the women were suspected of having parotitis their serum amylase concentration

Clinical profiles of six pregnant women who developed enlarged salivary gland

\begin{tabular}{ccccccr}
\hline & & \multicolumn{4}{c}{ Ritodrine treatment } & Peak serum amylase \\
\cline { 3 - 6 } Case No & Age (years) & Parity & $\begin{array}{c}\text { Gestational week } \\
\text { of administration }\end{array}$ & $\begin{array}{c}\text { Average rate during } \\
\text { first } 12 \mathrm{~h}(\mu \mathrm{g} / \mathrm{min})\end{array}$ & Duration & $\begin{array}{c}\text { (U) } \\
\text { pancreas isoenzymes) }\end{array}$ \\
\hline 1 & 26 & 0 & 20 & 76 & 23 days & $300(7 \cdot 5: 2 \cdot 5)$ \\
2 & 28 & 1 & 35 & 270 & 11 hours & $510(8 \cdot 3: 1 \cdot 7)$ \\
3 & 31 & 1 & 34 & 167 & 53 hours & $2572(9 \cdot 6: 0 \cdot 4)$ \\
4 & 28 & 0 & 12 & 83 & 8 days & $1560(8 \cdot 6: 1 \cdot 4)$ \\
5 & 30 & 1 & 34 & 100 & 62 hours & $4049(9 \cdot 6: 0 \cdot 4)$ \\
6 & 43 & 0 & 30 & 67 & 26 days & $3143(9 \cdot 6: 0 \cdot 4)$ \\
\hline
\end{tabular}

was determined. An abnormally high serum amylase level ( $>215 \mathrm{U} / \mathrm{l}$ ) was observed within the first 12 hours in all cases. The highest amylase concentration occurred at 12 to 36 hours in all but one patient (case 4). The raised amylase concentration was shown to be exclusively derived from the salivary glands by the analysis of isozyme pattern (table). Serological tests for mumps infection (enzyme linked immunosorbent assay kits provided by Behring, Germany, for measuring immunoglobulin $\mathrm{G}$ and $M$ antibodies to mumps virus, and mumps microneutralisation assay conducted by SRL, Japan), performed in paired serum samples from five patients, ruled out mumps. Although follow up amylase concentrations were not determined in three patients, in the other three (cases 1, 5, and 6) they returned to normal within 14 days. All six women had healthy babies, and neither mothers nor children had any other abnormalities.

\section{Comment}

Six pregnant women developed symptoms of parotitis several hours after the administration of ritodrine hydrochloride. Serological tests performed in five of them excluded the possibility of mumps infection.

The clinical side effects of ritodrine reflect its $\beta$ mimetic activity. ${ }^{2}$ To our knowledge, however, $\beta$ mimetics have not been reported to have an effect on the salivary gland in humans, though Selye observed that another $\beta$ mimetic agent, isoprenaline, induced hypertrophy of the salivary gland in rats. ${ }^{3}$ Following this observation the relation between adrenergic agents and salivary gland function was investigated in rats since hypertrophy of the salivary gland and hypersecretion of amylase occur via the stimulation of $\beta$ adrenoceptors. ${ }^{4}$ In vitro experiments showed that human salivary gland tissues also secrete amylase in response to isoprenaline. ${ }^{5}$ The hypersecretion of amylase and the swelling of the salivary glands in our six patients therefore probably resulted from the administration of ritodrine hydrochloride. Clinicians should be aware of this adverse effect of ritodrine, which might also occur in women receiving other $\beta_{2}$ agonists for the treatment of premature labour.

Rush RW, Keirse MJNC, Howat P, Baum JD, Anderson ABM, Turnbull AC Contribution of preterm delivery to perinatal mortality. $B M \mathcal{F} 1976$;ii:965-8.

Barden TP, Peter JB, Merkatz IR. Ritodrine hydrochloride: a betamimetic agent for use in preterm labor. Obstet Gynecol 1980;56:1-6.

Selye $H$, Veilleux R, Cantin M, Excessive stimulation of salivary gland growth by isoproterenol. Science 1961;133:44-5.

McPherson MA . Hales $\mathrm{CN}$. Control of amylase biosynthesis and release in the person

parid gland

Defective $\beta$-adrenergic secretory responses in submandibular acinar cells Defective $\beta$-adrenergic secretory responses in subm

(Accepted 18 March 1992)
Correspondence to: $\mathrm{Dr}$ Chauhan.

BMF 1992;304: 1668-9

\section{Regular balloon inflation for patients with chronic bronchitis: a randomised controlled trial}

\author{
Anoop J Chauhan, John P McLindon, \\ Patrick Dillon, James P C Sawyer, Linda Gray, \\ Bernard C Leahy
}

Patients with severe airways obstruction due to chronic bronchitis and emphysema are disabled by their symptoms, particularly breathlessness. Regular lung exercises can reduce the severity of their symptoms, ${ }^{1 \cdot-3}$ but these are expensive and demand resources from a multidisciplinary team. We had observed that even patients with severe airways limitation could blow up ordinary rubber balloons so we investigated whether the simple exercise of regularly inflating a balloon could improve exercise tolerance and reduce the severity of breathlessness experienced by such patients.

\section{Patients, methods, and results}

The study was approved by the local medical ethics committee. Twenty eight patients were randomly recruited (by random numbers sampling from full clinic list) from an outpatient respiratory clinic over six months with the following inclusion criteria: $(a)$ spirometrically proved airways obstruction (a ratio of forced expiratory volume in one second $\left(\mathrm{FEV}_{1}\right)$ to 
Department of Medicine, Trafford General Hospital Manchester M31 3SL

Anoop J Chauhan, medical registrar

John P McLindon, medical registrar

Patrick Dillon, medical registrar

James P C Sawyer, senior house officer

Linda Gray, chief

physiological measurement

technician

Bernard C Leahy, consultant physician forced vital capacity (FVC) of $<0 \cdot 70$ ); (b) $\mathrm{FEV}_{1}<1$ litre on at least three separate clinic assessments; $(c)$ willingness to be randomised, either to blow up balloons or not to blow them up; and $(d)$ willingness, if randomised to balloon blowing, to inflate balloons regularly at home, unsupervised, for eight weeks. Patients whose treatment was likely to change during the study period were excluded. The 13 patients randomised to the study group (six men) had a mean age of $65 \cdot 4$ years and a mean $\mathrm{FEV}_{1}: \mathrm{FVC}$ ratio of $0 \cdot 43$. The 15 controls (nine men) had a mean age of 69 years and an $\mathrm{FEV}_{1}: \mathrm{FVC}$ ratio of $0 \cdot 46$.

We supplied patients in the study group with a centimetre ruler and asked them to inflate one new ordinary rubber balloon to a diameter of $20 \mathrm{~cm} 40$ times a day for eight weeks. These requirements were arrived at arbitrarily.

At the start of the study two pulmonary technicians who were unaware of the allocation of patients assessed the baseline six minute walking distance; three standardised six minute walking tests were performed but only the third recorded (to allow for the initial burst of speed, after which patients walk at a constant rate). The patients themselves recorded on a diary sheet baseline visual analogue scores for severity of breathlessness $(0=$ least, $10=$ worst $)$ and degree of well being $(0=$ worst, $10=$ best $)$. Scales were reversed on the assumption that each patient would consider each variable on its own merit and not equate the two symptoms.

Both groups then recorded their breathlessness and well being daily for the eight weeks and returned for final assessment of six minute walking distance. Two

Median distances on six minute walking test and median scores for breathlessness and well being before and after regular balloon inflation for eight weeks

\begin{tabular}{|c|c|c|c|c|c|}
\hline & Balloon group & Controls & $\begin{array}{l}\text { W' Mann- } \\
\text { Whitney statistic } \\
\text { (sum of ranks in } \\
\text { first sample) }\end{array}$ & $\begin{array}{l}\text { Median of differences } \\
(95 \% \text { confidence interval) }\end{array}$ & p Value \\
\hline \multicolumn{6}{|c|}{6 Min walk (metres): } \\
\hline Before & $279 \cdot 5$ & $228 \cdot 5$ & 134 & $12 \cdot 6(-62 \cdot 1$ to 86$)$ & $0 \cdot 64$ \\
\hline After & 300 & $258 \cdot 0$ & 152 & $36.5(-34$ to 120$)$ & $0 \cdot 10$ \\
\hline \multicolumn{6}{|c|}{ Wellbeingt: } \\
\hline Before & 32 & 37 & $116 \cdot 5$ & $-3(-11$ to 10$)$ & $0 \cdot 53$ \\
\hline After & 48 & 40 & $152 \cdot 5$ & $-9(-3$ to 21$)$ & 0.08 \\
\hline \multicolumn{6}{|c|}{ Breathlessness: } \\
\hline Before & 35 & 36 & 109 & $-2(-10$ to 4$)$ & $0 \cdot 41$ \\
\hline After & 30 & $36 \cdot 5$ & $89 \cdot 5$ & $-9(-18$ to -1$)$ & $0 \cdot 02$ \\
\hline
\end{tabular}

ॠTwo sided test for null hypothesis. †Total weekly score on visual analogue scale. patients were excluded from the study group as they failed to inflate balloons regularly. Compliance otherwise was good. Four patients were excluded from the control group: two were admitted to hospital (heart failure and pneumonia) and two failed to attend for repeat assessment. Eleven patients in each group therefore completed the study. Non-parametric analyses were performed in view of the small sample size.

The table shows a significant reduction in the breathlessness score after regular balloon inflation, together with slight, though non-significant, improvements in well being and six minute walking distance in the balloon group.

\section{Comment}

Whether the perceived reduction in breathlessness resulted from a true physiological training effect or from "desensitisation" to breathlessness is not easily ascertained." "Well being" is also a multifactorial concept, encompassing social, emotional, intellectual, and psychological factors, aspects that we were not able to measure. ${ }^{5}$ Instead we used a simple visual analogue scale to ensure patient compliance. The improvements in both measures might have been due to the patients' greater sense of control over their disability. Alternatively the difference in scores between the balloon and control groups might have been caused by a "negative placebo" effect in the controls as they were aware that they were not performing the exercise.

Nevertheless, balloon inflation is easily performed at home by patients with littie or no supervision, and our results suggest that it might be a cheap and costeffective method of pulmonary rehabilitation. The potential benefits of this simple form of lung exercise require further research.

1 Cockroft AE, Saunders MJ, Berry G. Randomised controlled trial of rehabilitation in chronic respiratory disease. Thorax 1981;36:200-3.

2 Sinclair DJM, Ingram CG. Conrolled trial of supervised exercise training in chronic bronchitis. BMJ 1980;i:519-21.

3 Belman MJ, Mittman C. Ventilatory muscle training improves exercise capacity in chronic obstructive pulmonary disease. Am Rev Respir Dis 1980;121: $273-80$.

4 Guyatt GH, Townsend M, Keller J, Singer J, Nogradi F. Respiratory Medicine 1991;85(supp B):17-21.

5 Belman MJ, Brook LR, Ross DJ, Mohsenifar $Z$. Variability of breathlessnes measurement in patients with chronic obstructive pulmonary disease. Ches 1991;99:566-71

(Accepted 18 March 1992)

\section{ONE HUNDRED YEARS AGO}

\section{NURSES AND THEIR WORK}

SIR,-May I request the favour of a short space in the BRITISH MEDICAL JouRnal to offer a few remarks on the subject of nurses and their work? I have had to employ more nurses than usual during the last eighteen months, and I have found that although, as a rule, they perform the ordinary duties of their calling more or less fairly well, yet it is rare to meet with a nurse who takes any great or intelligent interest in her case. When, for example, a nurse has been needed for a very severe case under special observation, it has been hardly possible to find one adequately qualified for the work; and when fortunately such a rare treasure has been once secured, and application has been made to the nursing institution for her services in another case of a similar kind, it has usually not been possible to engage her again, owing to her having been sent off to some case in which no special intelligence is required. It may be freely admitted that institutions for nurses are very valuable, but surely it would be possible to adopt some plan for the classification of nurses, so as to distinguish between those who have gone in for steady and scientific progress, and those who have not. It was only last week that a lady told me that a nurse obtained from an institution was on night duty at her house in the country, and that when a well-known London physician was sent for in consultation, the nurse, much to the lady's surprise did not care to remain up, even for the short time needed to receive her orders from the consulting doctor. Such cases are far from being exceptional, and my own experience is very much the same, when the time has come for the nurse to be off duty, or to have her Sunday out. The few really good and efficient nurses I have been fortunate enough to engage for some of my more important cases have been worth far more than the usual fee of two guineas a week; whilst, on the other side, a nurse who has not had the opportunity of going through the preliminary period of three years' training may often be very useful, and, in chronic cases, ready to keep her engagement.

In conclusion, it may be asked, whether it would not be possible to establish a higher standard for those nurse who have received a superior education, and who may be not only willing but also anxious still further to improve? -I am, etc.

Gloucester Place, W (BMF 1892;i:787.) 